\title{
Seasonal dynamics of dissolved organic carbon, nitrogen and other nutrients in soil of Pinus massoniana stands after pine wilt disease disturbance
}

\author{
P. Ge ${ }^{1}$, L.J. Da, ${ }^{1,2,3^{*}}$ W.B. Wang ${ }^{1}$ and X.N. Xu ${ }^{4}$ \\ ${ }^{1}$ Department of Environmental Science, East China Normal University, Shanghai 200241, P.R. China. ${ }^{2}$ Tiantong National Station \\ of Forest Ecosystem, Shanghai 200241, P.R. China. ${ }^{3}$ Shanghai Key Laboratory for Ecology of Urbanization Process and Eco- \\ restoration, Shanghai 200241, P.R. China. ${ }^{4}$ College of Forestry and Landscape Architecture, Anhui Agricultural University, Hefei \\ 230036, P.R. China. *Corresponding author: green-apple1982@163.com
}

\begin{abstract}
To understand changes in soil nutrients in Pinus massoniana forests affected by pine wilt disease (PWD), we examined the seasonal variation in dissolved organic carbon (DOC), dissolved organic nitrogen (DON) and soil nutrients in Hefei, East China. The results showed a considerable decline in the population density and basal area in both highly disturbed (HD) and moderately disturbed (MD) forest stands and an increase in dead pine trees, causing pronounced changes in the stand structure and soil nutrient status. The concentrations of DOC and $\mathrm{NO}_{3}^{-}-\mathrm{N}$ were significantly $(p<0.05)$ higher in every season in the disturbed forests compared to the undisturbed (UD) forest stand. However, during spring and summer, the variation in the DON and $\mathrm{NH}_{4}^{+}-\mathrm{N}$ values was significantly $(p<$ 0.05 ) lower in the HD forest stand than in the UD stand; total $\mathrm{N}$ concentrations were higher in the disturbed forests in every season. During spring and autumn, the variation in total P values was significantly $(p<0.05)$ lower in the MD forest stand than in the UD stand, whereas the total P values were significantly $(p<0.05)$ lower in every season in the HD stand than in the UD stand. In this study, disturbance resulted in a considerable increase in DOC, N and $\mathrm{NO}_{3}^{-}-\mathrm{N}$ when compared to the UD stand and a pronounced increase in soil nitrate in the HD stand, which may lead to soil acidification, thereby increasing the possibility of soil nutrient leaching.
\end{abstract}

Keywords: Pinus massoniana forest, dissolved organic carbon (DOC), dissolved organic nitrogen (DON), soil properties, disturbance

\section{Introduction}

Pine wilt disease (PWD) is caused by epidemic attacks of the nematode Bursaphelenchus xylophilus, a species that is vectored by a beetle (Morimoto and Iwasaki, 1972), and has become a problem that affects the vegetation of pine forests and landscapes (Fujihara, 1995). In addition to their role in soil properties, an understanding of the dynamics of soil nutrients following forest disturbances is crucial for the development of timed strategies for the management of damaged lands. Indeed, soil nutrients can be quite variable in different forest types, stand ages, landscapes and disturbance regimes, and the level of soil nutrients also depends upon several key abiotic factors, including the total rainfall and seasonality of the rainfall and disturbance. 
Significantly, PWD disturbance results in an opening of the forest canopy and alterations in the forest floor microenvironment that decrease the soil nutrient level. The soil solution chemistry is often a sensitive indicator of biogeochemical processes in forests because it quickly responds to various disturbances, and numerous studies exploring the effects of disturbance on forest soil solution chemistry and fluxes over the past two decades have focused on inorganic nutrients (Knight et al., 1991; Prescott, 1997). Recent work has revealed that soil dissolved organic carbon (DOC) and nitrogen (DON) are mobile with the soil solution and are thus considered to play a major role in soil processes, representing a key component of biogeochemical cycles (Kaiser et al., 2001; Kalbitz et al., 2000). In comparison to inorganic $\mathrm{N}\left(\mathrm{NH}_{4}^{+}\right.$and $\mathrm{NO}_{3}^{-}$), DON to central in the $\mathrm{N}$ cycle as a potential source for both microorganisms and plants (Kalbitz et al., 2000; Neff et al., 2003; Schimel and Bennett, 2004). Moreover, DOC and DON are very sensitive to small changes in soil circumstances (e.g., degradation, erosion); thus, they provide highly accurate and direct information on soil quality.

A growing number of studies have revealed the effect of soil properties on DOC or DON concentration and quality. The production and leaching of DOC is affected by biological factors (McDowell and Likens, 1988; Boissier and Fontvieille, 1995; Christ and David, 1996; Brookes et al., 1999) and by chemical factors, such as $\mathrm{pH}$ (or liming) (Andersson and Nilsson, 2001; Filep et al., 2003). However, when compared to anthropogenic disturbances in forest soils (e.g., clear-cutting, land clearing, fire), much less attention has been focused on the effects of natural disturbances on soil properties. Therefore, the main objectives of this study were to analyze the dynamic changes in soil DOC, DON and edaphic elements, such as N, P and $\mathrm{K}$, after Bursaphelenchus xylophilus infection in a subtropical coniferous forest in western Hefei. We hypothesized that the seasonal dynamics of DOC, DON and other nutrients would show pronounced changes in response to the decline in forest health predicted to occur with pine wilt disease disturbance.

\section{Materials and Methods}

\subsection{Study Area}

This field study was conducted in a suburban forest park located in Hefei, Anhui Province in the north subtropical area of East China ( $31^{\circ} 50^{\prime} \mathrm{N}$ and $117^{\circ} 15^{\prime}$ E). The climate of this area is subtropical monsoon, with a hot and humid summer and a dry and cold winter. The annual mean precipitation is $969.5 \mathrm{~mm}$, and rainfall is strongly seasonal, with seven dry months per year and $70 \%$ of the annual rainfall falling from June to August. Because of the rainfall seasonality, most of the tree species drop their leaves at the end of the rainy season, which represents a new input of organic matter to the soil. During the study period, the average monthly temperature was $15.7{ }^{\circ} \mathrm{C}$, with average monthly minimum and maximum temperatures of 2.6 and $31.0^{\circ} \mathrm{C}$ in January and July, respectively. The annual mean relative humidity reaches $75 \%$.

The common vegetation in this forest park consists of forest plantations, which account for nearly $90 \%$ of the total area. The land area is mainly composed of pioneer Pinus massoniana forests (approximately $200 \mathrm{ha}$ ) and other compatible shrub layers, including Liquidambar formosana, Ulmus pumila, Celtis sinensis, Broussonetia papyrifera, Rhus chinensis and Dalbergia hupeana. PWD was first found in this forest park in 1998, and the majority of the forests suffered a serious disturbance due to PWD from 2002 to 2008, resulting in the death of a large number of pine trees. By 2008, almost all the dead trees were removed by the local forestry managers (personal communication with local forest managers). A well-developed soil profile with a distinct litter layer and an organic horizon extending to a depth of $3 \mathrm{~cm}$ has been maintained in the undisturbed forest since 2009 . In contrast, the organic horizon at the disturbed sites was very thin and less distinct because of the absence of a litter layer. Such variations are attributed to the nature and intensity of disturbance at the site. The soils are sandy clay loams, classified as Eutric Regosols in the FAO (Food and Agriculture Organization of the United Nations) system. 
Table 1. Basic conditions of the studied undisturbed (UD), moderately disturbed (MD) and highly disturbed (HD) forest stands.

\begin{tabular}{|c|c|c|c|c|c|c|}
\hline \multirow{3}{*}{ Physical parameter } & \multicolumn{6}{|c|}{ Study site } \\
\hline & UD & & MD & & HD & \\
\hline & 2002 & 2009 & 2002 & 2009 & 2002 & 2009 \\
\hline \multicolumn{7}{|l|}{ Vegetation } \\
\hline \multicolumn{7}{|l|}{ Density $\left(\mathrm{ha}^{-1}\right)$} \\
\hline P. massoniana & 1100 & 1100 & 1150 & 850 & 1075 & 475 \\
\hline Shrubs & 560 & 786 & 575 & 750 & 550 & 800 \\
\hline Grasses & 1380 & 1400 & 1369 & 3645 & 1366 & 4028 \\
\hline \multicolumn{7}{|l|}{ Basal area $\left(\mathrm{m}^{2} \mathrm{ha}^{-1}\right)$} \\
\hline P. massoniana & 26.36 & 31.74 & 24.66 & 20.74 & 27.05 & 21.71 \\
\hline Shrubs & 4.18 & 6.05 & 5.01 & 5.35 & 4.16 & 5.96 \\
\hline \multicolumn{7}{|l|}{ Mean DBH $(\mathrm{cm})$} \\
\hline P. massoniana & 17.91 & 24.61 & 18.10 & 21.81 & 18.11 & 20.13 \\
\hline Shrubs & 7.76 & 9.44 & 6.93 & 7.34 & 7.52 & 8.15 \\
\hline \multicolumn{7}{|l|}{ Mean height (m) } \\
\hline P. massoniana & 12.71 & 17.96 & 13.85 & 17.44 & 13.66 & 16.97 \\
\hline Shrubs & 7.03 & 7.40 & 7.11 & 8.67 & 7.25 & 7.73 \\
\hline \multicolumn{7}{|l|}{ Microclimate } \\
\hline Light intensity (Lux) & $\begin{array}{l}2186.02 \\
(110.01) \mathrm{c}\end{array}$ & $\begin{array}{l}2047.11 \\
(120.06) \mathrm{c}\end{array}$ & $\begin{array}{l}2257.06 \\
(109.21) \mathrm{c}\end{array}$ & $\begin{array}{l}12273.66 \\
(131.89) b\end{array}$ & $\begin{array}{l}2298.78 \\
(115.31) \mathrm{c}\end{array}$ & $\begin{array}{l}18331.64 \\
(140.60) \mathrm{a}\end{array}$ \\
\hline Soil temperature $\left({ }^{\circ} \mathrm{C}\right)$ & $\begin{array}{l}19.32 \\
(0.30) \mathrm{b}\end{array}$ & $\begin{array}{l}19.44 \\
(0.32) \mathrm{b}\end{array}$ & $\begin{array}{l}19.54 \\
(0.21) \mathrm{b}\end{array}$ & $\begin{array}{l}23.65 \\
(2.08) \mathrm{a}\end{array}$ & $\begin{array}{l}19.61 \\
(0.18) \mathrm{b}\end{array}$ & $\begin{array}{l}24.54 \\
(2.16) \mathrm{a}\end{array}$ \\
\hline Litter depth (cm) & 3.05 & 3.51 & 2.98 & 1.28 & 3.01 & 0.65 \\
\hline Standing dead trees $\left(\mathrm{ha}^{-1}\right)$ & $(0.21) \mathrm{b}$ & $\begin{array}{l}(0.11) \mathrm{a} \\
0\end{array}$ & $(0.12) \mathbf{b}$ & $\begin{array}{l}(0.18) \mathrm{c} \\
35\end{array}$ & $(0.03) \mathrm{b}$ & $\begin{array}{l}(0.07) \mathrm{d} \\
70\end{array}$ \\
\hline
\end{tabular}

Note: The stand density and growth parameters were calculated based on the trees with $\mathrm{DBH}>4.0 \mathrm{~cm}$ within the plot. The values in the same row with different letters are significantly different at the $5 \%$ level; the standard deviations are listed in parentheses $(n=4)$.

Table 2. Physical characteristics of selected soils $(0-20 \mathrm{~cm})$ from undisturbed (UD), moderately disturbed (MD) and highly disturbed (HD) forest stands.

\begin{tabular}{|c|c|c|c|c|c|c|}
\hline Soil property & UD & & $\begin{array}{l}\text { Study site } \\
\text { MD }\end{array}$ & & HD & \\
\hline Depth $(\mathrm{cm})$ & $0-20$ & & $0-20$ & & $0-20$ & \\
\hline Texture & & & & & & \\
\hline Sand (\%) & $30.70(0.15) \mathrm{c}$ & & $36.85(0.31) b$ & & $47.81(0.22) \mathrm{a}$ & \\
\hline Silt (\%) & $33.21(0.21) \mathrm{a}$ & & $30.11(0.11) b$ & & $26.70(0.12) \mathrm{c}$ & \\
\hline Clay (\%) & $36.09(0.33) \mathrm{a}$ & & $33.04(0.41) b$ & & $25.49(0.33) c$ & \\
\hline WHC (\%) & $50.96(5.85) \mathrm{a}$ & & $42.06(1.86) \mathrm{b}$ & & $39.09(1.15) \mathrm{b}$ & \\
\hline Bulk density $\left(\mathrm{g} \cdot \mathrm{cm}^{-3}\right)$ & $1.13(0.02) \mathrm{C}$ & & $1.29(0.01) \mathrm{b}$ & & $1.34(0.01) \mathrm{a}$ & \\
\hline Depth $(\mathrm{cm})$ & $0-10$ & $10-20$ & $0-10$ & $10-20$ & $0-10$ & $10-20$ \\
\hline Moisture (\%) & $29.23(0.88) a$ & $30.01(1.02) \mathrm{a}$ & $23.96(0.03) \mathrm{c}$ & $28.62(0.06) b$ & $20.65(0.01) \mathrm{e}$ & $22.89(0.01) \mathrm{d}$ \\
\hline $\mathrm{pH}\left(\mathrm{H}_{2} \mathrm{O}\right)$ & $4.21(0.18) \mathrm{c}$ & $4.85(0.15) \mathrm{ab}$ & $4.49(0.14) \mathrm{bc}$ & $5.16(0.08) a$ & $4.54(0.12) \mathrm{bc}$ & $5.06(0.11) \mathrm{a}$ \\
\hline $\mathrm{EC}\left(\mu \mathrm{S} \cdot \mathrm{cm}^{-1}\right)$ & $103.56(1.89) \mathrm{a}$ & $102.11(2.11) \mathrm{a}$ & $88.86(1.49) \mathrm{b}$ & $85.66(1.34) b$ & $66.52(7.47) \mathrm{c}$ & $66.32(5.42) \mathrm{c}$ \\
\hline Organic matter (\%) & $3.87(0.05) \mathrm{a}$ & $3.06(0.07) \mathrm{c}$ & $3.41(0.03) \mathrm{b}$ & $2.72(0.11) \mathrm{d}$ & $3.19(0.06) c$ & $1.62(0.05) \mathrm{e}$ \\
\hline
\end{tabular}

Note: The values in the same row with different letters are significantly different at the $5 \%$ level; the standard deviations are listed in parentheses $(n=4)$. 
The parent materials are Mesozoic sediments and acidic intrusive rocks, including quartzite and granite. Additional information on the stand structure (size class and importance values of the soil properties) is presented in Tables 1 and 2 .

\subsection{Experimental Design}

We selected three Pinus massoniana stands: an undisturbed (UD) stand, a highly disturbed (HD) stand and a moderately disturbed (MD) stand. The three forest types used for this study were located on similar topography (lower slopes) and had the same original vegetation. Soil samples were separately collected under the Pinus massoniana stands in September 2009 (autumn), December 2009 (winter), March 2010 (spring) and June 2010 (summer). Four replicate soil samplings were performed for each season and each stand $(40 \mathrm{~m} \times 40 \mathrm{~m})$. Each stand was separated into four areas, and randomly distributed pits $(120 \mathrm{~cm} \times 80$ $\mathrm{cm})$ were dug in each area; after removing the forest floor, soil samples were collected at two different soil depths $(0-10 \mathrm{~cm}$ and $10-20 \mathrm{~cm})$. In the laboratory, visible roots were removed from the fresh soil samples, which were sieved to pass through a $2-\mathrm{mm}$ screen and then stored in plastic bags at $4{ }^{\circ} \mathrm{C}$. Subsamples were removed for the determination of DOC, total dissolved nitrogen (TDN) and soil physicochemical properties.

\subsection{Laboratory Analyses}

DOC and TDN were extracted using the method of Jones and Willett (2006). In brief, $20 \mathrm{~g}$ of fresh soil was extracted with $100 \mathrm{~mL}$ of ultra-pure water in a plastic bottle by shaking the mixture for $1 \mathrm{~h}$ on a reciprocal shaker. The supernatant was filtered through a GF/F glass-fiber filter. The DOC and TDN in the extracts were also measured using a $\mathrm{C} / \mathrm{N}$ analyzer (Multi-N/C 3100; Analytik Jena, Germany). DON was calculated as $\mathrm{TDN}-\left(\mathrm{NH}_{4}^{+}-\mathrm{N}+\mathrm{NO}_{3}^{-}-\mathrm{N}\right)$.

Soil inorganic $\mathrm{N}\left(\mathrm{NH}_{4}{ }^{+}-\mathrm{N}\right.$ and $\left.\mathrm{NO}_{3}{ }^{-} \mathrm{N}\right)$ was measured in an extract obtained by mixing a 30 -g soil sample with $60 \mathrm{~mL}$ of $2 \mathrm{M} \mathrm{KCl}$ in an end-over-end shaker for $1 \mathrm{~h}$, and the extracts were filtered using a $\mathrm{GF} / \mathrm{F}$ glass-fiber filter. $\mathrm{NH}_{4}^{+}-\mathrm{N}$ was determined with an auto-analyzer using a standard alkaline phenol method, and $\mathrm{NO}_{3}^{-}$ $-\mathrm{N}$ was determined colorimetrically (Anderson and Ingram, 1993).

After air-drying the remainder of the soil samples, the total soil $\mathrm{N}$ concentration was analyzed using an auto-Kjeldahl analyzer. Subsamples $(0.5 \mathrm{~g})$ were first digested in nitric and perchloric acids, and the total soil $\mathrm{P}$ concentration was determined using a Spectronic colorimeter (Kuo, 1996). The exchangeable soil cations (K) were analyzed by extracting 5-g subsamples with ammonium acetate (Helmke and Sparks, 1996; Suarez, 1996); a Jenway flame photometer was used to determine the $\mathrm{K}$ concentration. The soil $\mathrm{pH}$ was determined potentiometrically in distilled water (soil:water ratio of 1:2.5) after end-over-end mixing for $1 \mathrm{~h}$ and a settling time of $15 \mathrm{~min}$. The soil moisture was measured gravimetrically by incubating $10 \mathrm{~g}$ of fieldmoist soil sample in a hot-air oven at $105^{\circ} \mathrm{C}$ for $24 \mathrm{~h}$. The soil water holding capacity (WHC) was measured according to Ilstedt et al. (2000). The samples were placed in plastic cylinders (height, $20 \mathrm{~mm}$; diameter, $25 \mathrm{~mm}$ ) with nylon mesh bottoms, soaked in water for $12 \mathrm{~h}$ and drained for $1 \mathrm{~h}$ prior to drying at $105{ }^{\circ} \mathrm{C}$ for $12 \mathrm{~h}$. WHC was calculated as the mass ratio between the water content difference, as measured before and after drying, and the dry soil. The bulk density was determined by drying $1 \mathrm{~cm}^{3}$ of each peat replicate at $105{ }^{\circ} \mathrm{C}$ for $24 \mathrm{~h}$. The clay $(<2 \mu \mathrm{m})$, silt $(2-20 \mu \mathrm{m})$ and sand $(20-2000 \mu \mathrm{m})$ contents were determined by a particle size analysis (using the pipette method) and defined according to the Australian classification system (McKenzie et al., 2002).

\subsection{Statistical Analysis}

Four replicates were obtained from each stand, and all the samples were randomly selected for collection. One-way analyses of variance (ANOVA) with the Tukey test at the 5\% level were used to identify the soil properties. The least significant differences 
(LSDs, $\mathrm{P}=0.05$ ) were calculated to separate the differences among the soil total N, P and K. All the statistical analyses were performed using SPSS 12.0 software (SPSS Inc., USA).

\section{Results}

\subsection{Changes in Stand Structure after PWD Disturbance}

PWD disturbance resulted in considerable changes in the microclimate and stand structure of the forest (Table 1). The soil temperature and light intensity were significantly $(p<0.05)$ lower in the UD forest stand $\left(19.44{ }^{\circ} \mathrm{C}, 2047.11 \mathrm{Lux}\right)$ compared to the MD stand $\left(22.65^{\circ} \mathrm{C}, 12273.66 \mathrm{Lux}\right)$ and HD stand $(24.54$ ${ }^{\circ} \mathrm{C}, 18331.64$ Lux) in 2009 (Table 1). During 20022009 , there was a $26.1-55.8 \%$ decline in the population density of Pinus massoniana in both the MD and HD stands compared to the UD stand, and the density of the shrubs and grasses significantly $(p<0.05)$ increased along the disturbance gradient (Table 1). The basal area of Pinus massoniana decreased over 15.8\% and $19.7 \%$ in the MD and HD stands, respectively, yet increased by $20.4 \%$ in the UD stand (Table 1 ).

\subsection{Soil Characteristics}

In the three soil samples, the levels of moisture at the $0-10-\mathrm{cm}$ depth were lower than those at $10-20 \mathrm{~cm}$, whereas the soil electrical conductivity value and organic matter at $0-10 \mathrm{~cm}$ were higher than those at $10-20 \mathrm{~cm}$ (Table 2). The soil was acidic $(\mathrm{pH} 4.21-$ 5.16) and showed significant variation between the two depths in each stand. In the UD forest stand, the soil moisture content, WHC, electrical conductivity value and organic matter were significantly $(p<0.05)$ higher compared to the disturbed stands (Table 2). The clay and slit content were also significantly ( $p$ $<0.05$ ) higher in the UD stand and declined along the disturbance gradient. The soil bulk density was significantly $(p<0.05)$ lower in the UD stand than in the disturbed stands (Table 2).

\subsection{Dissolved Organic Carbon (DOC) and Nitrogen (DON)}

The concentrations of DOC and DON decreased with soil depth in the different stands and seasons (Figure 1a and 1b). In every season, the soil DOC concentration was significantly $(p<0.05)$ higher in the disturbed stands than in the UD stand. The peak DOC values were $111.34,117.29$ and $136.96 \mathrm{mg} \mathrm{kg}^{-1}$ during summer in the UD, MD and HD stands, respectively, and the minimum values were 50.20 and $52.38 \mathrm{mg} \mathrm{kg}^{-1}$ in the MD and HD stands, respectively, during winter. The soil DON values ranged from 6.89 to $18.01 \mathrm{mg}$ $\mathrm{kg}^{-1}$ in the UD stand, 6.64 to $20.40 \mathrm{mg} \mathrm{kg}^{-1}$ in the MD stand and 3.68 to $25.81 \mathrm{mg} \mathrm{kg}^{-1}$ in the HD stand (Figure 1b). During spring and summer, the variation in DON values was significantly $(p<0.05)$ lower in the disturbed stands than in the UD stand, whereas the DON values were significantly $(p<0.05)$ higher during winter and autumn in the disturbed stands than the UD stand. In all three stands, the average soil DON concentrations were ranked as winter $>$ autumn $>$ summer $>$ spring (data not shown).

\subsection{Inorganic Nitrogen}

The minimum values for the soil $\mathrm{NH}_{4}^{+}-\mathrm{N}$ concentration were 5.84 and $5.04 \mathrm{mg} \mathrm{kg}^{-1}$ in the UD and MD stands, respectively, during autumn. The maximum value was recorded during spring in the UD stand (10.11 $\left.\mathrm{mg} \mathrm{kg}{ }^{-1}\right)$ and during summer in the MD stand (9.25 $\mathrm{mg} \mathrm{kg}{ }^{-1}$ ) (Figure 1c). In the $\mathrm{HD}$ stand, the $\mathrm{NH}_{4}^{+}-\mathrm{N}$ concentrations ranged from 2.98 to $9.37 \mathrm{mg} \mathrm{kg}^{-1}$, with the maximum occurring in winter and the minimum in spring (Figure 1c).

Seasonally, the $\mathrm{NH}_{4}^{+}-\mathrm{N}$ values were significantly $(p<$ $0.05)$ lower during spring and summer in the HD stand than in either the UD or MD stand, whereas the $\mathrm{NH}_{4}{ }^{+} \mathrm{N}$ values were significantly $(p<0.05)$ higher during autumn and winter in the HD stand compared to the UD and MD stands (Figure 1c). The $\mathrm{NO}_{3}^{-}-\mathrm{N}$ concentrations markedly declined from the $0-10 \mathrm{~cm}$ to $10-20 \mathrm{~cm}$ depths $(p<0.05)$ in all three stands (Figure 1d). 
a

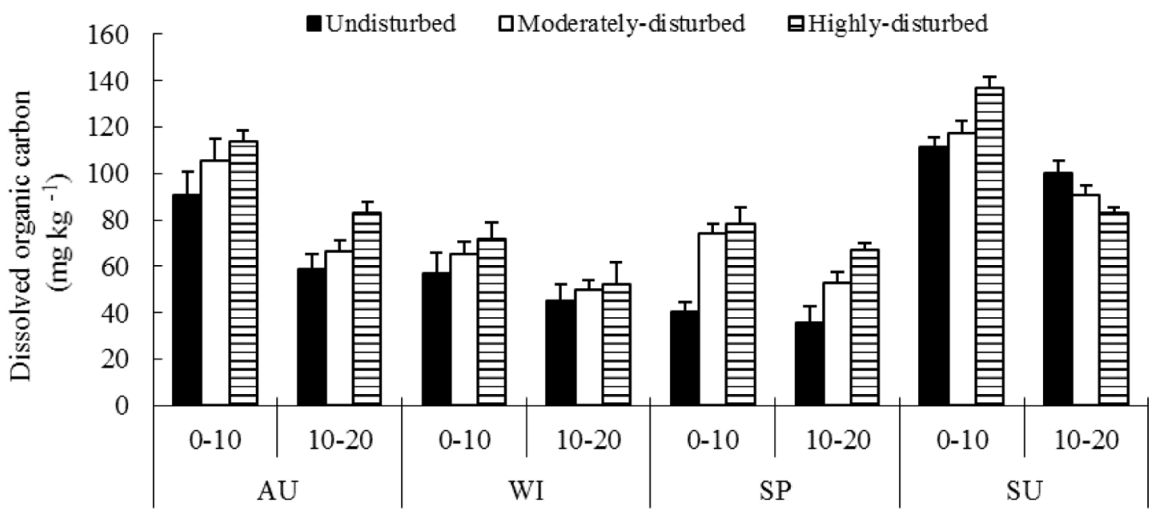

Soil depth (cm)

b

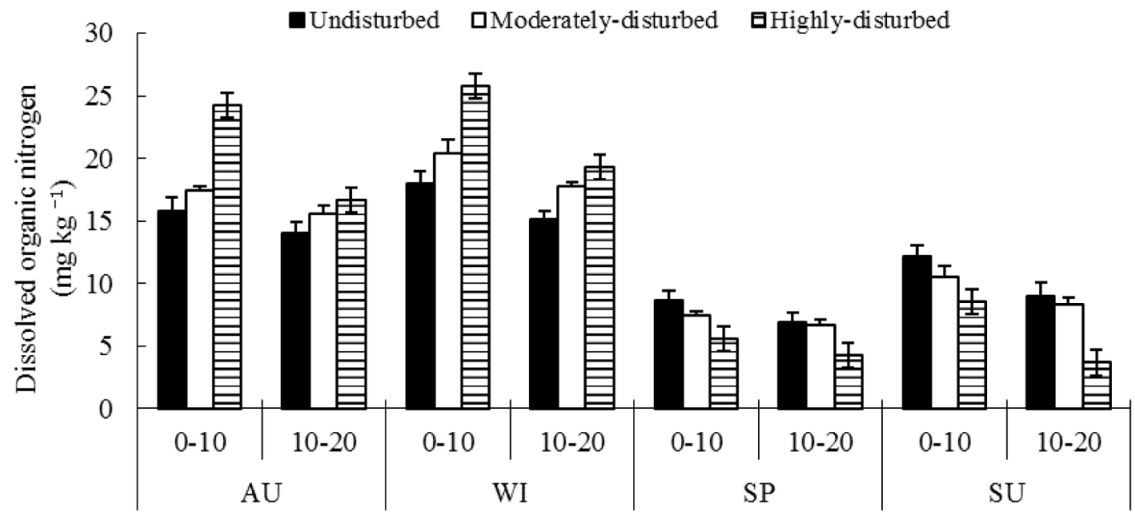

Soil depth (cm)

Figure1.a.b. Seasonal variation in dissolved organic (a) carbon and (b) nitrogen, at two soil depths (0-10 and $10-20 \mathrm{~cm}$ ) in undisturbed, moderately disturbed and highly disturbed forest stands. The vertical bars represent the standard errors of the means $(n=4)$. AU - autumn, WI - winter, SP - spring, SU - summer. 
c

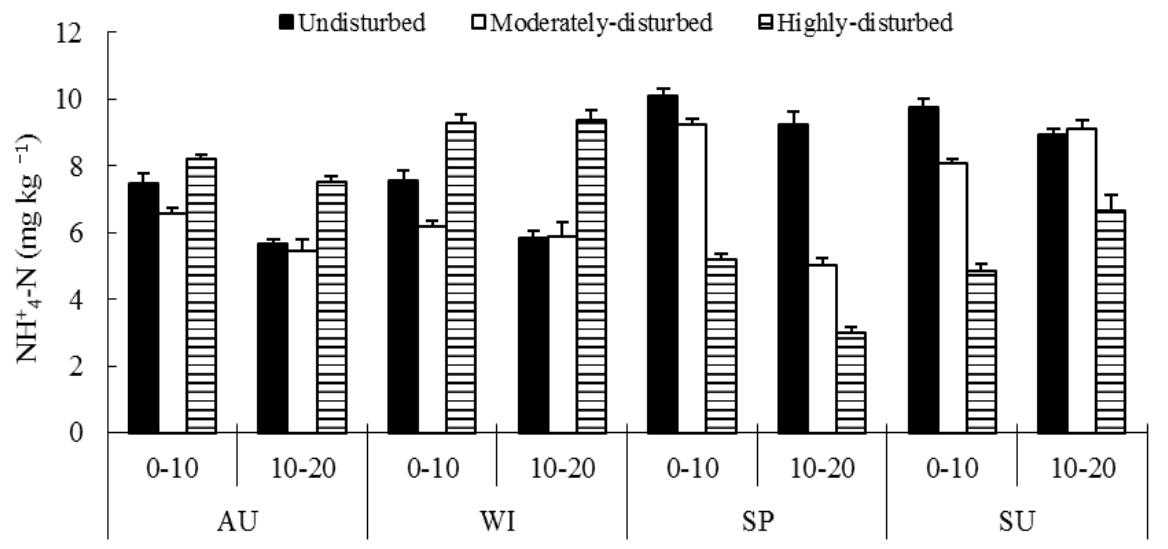

Soil depth (cm)

d

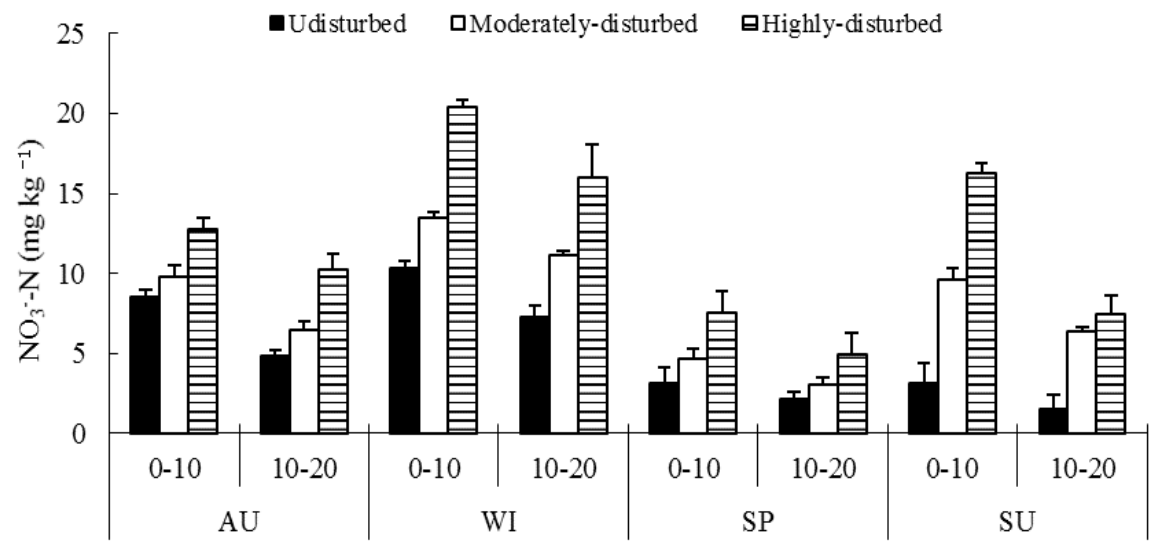

Soil depth (cm)

Figure1.c.d. Seasonal variation in (c) $\mathrm{NH}_{4}^{+}-\mathrm{N}$ and (d) $\mathrm{NO}_{3}^{-}-\mathrm{N}\left(\mathrm{mg} \mathrm{kg}^{-1}\right)$ at two soil depths $(0-10$ and 10-20 cm) in undisturbed, moderately disturbed and highly disturbed forest stands. The vertical bars represent the standard errors of the means $(n=4)$. AU - autumn, WI - winter, SP - spring, SU - summer. 
The maximum values for the soil $\mathrm{NO}_{3}-\mathrm{N}$ concentration were $10.33,13.51$ and $20.41 \mathrm{mg} \mathrm{kg}^{-1}$ during winter in the UD, MD and HD stands, respectively (Figure 1d), with minimum values recorded during summer in the UD stand (1.46 $\left.\mathrm{mg} \mathrm{kg}^{-1}\right)$ and spring in the MD (3.05 $\mathrm{mg} \mathrm{kg}^{-1}$ ) and $\mathrm{HD}\left(4.90 \mathrm{mg} \mathrm{kg}^{-1}\right)$ stands (Figure 1d). Moreover, the $\mathrm{NO}_{3}^{-} \mathrm{N}$ values were significantly $(p<$ 0.05 ) higher in each soil layer in the disturbed stands versus the UD stand.

\subsection{Soil Nutrients (N, P and K)}

In all three stands, the concentrations of total $\mathrm{N}$ showed a pronounced decrease with depth $(p<0.05)$, whereas the concentrations of total $\mathrm{K}$ showed a significant increase with depth (Table 3). Total N concentrations were higher in each soil layer in both the HD and MD stands compared to the UD stand in every season. With the exception of the spring season, the total $\mathrm{K}$ concentrations were significantly $(\mathrm{p}<0.05)$ higher in the UD stand than in the HD stand (Table 3). During spring and autumn, the variation in total $\mathrm{P}$ values was significantly $(p<0.05)$ lower in the MD stand than the UD stand, whereas the total $\mathrm{P}$ values were significantly $(p<0.05)$ lower in every season in the HD stand than the UD stand (Table 3 ).

\section{Discussion}

\subsection{Changes in Soil Physical Properties and Stand Structure after PWD Disturbance}

The greater soil WHC of the UD forest is attributed to the high clay and organic matter contents. The low soil organic matter in the disturbed stands may be attributed to less litter production and a faster decomposition rate, whereas the low soil $\mathrm{pH}$ in the UD forest compared to the disturbed sites could be the result of a lower rate of leaching, leading to a greater accumulation of reaction products in the soil. Disturbances influence stand structure by modifying the physical conditions (White and Pickett, 1985). For example, canopy dieback caused by disturbance influences the structure of stands by modifying the light conditions. Our results indicated that the Pinus massoniana forests suffered disturbance from PWD, which resulted in the death of some of the pine trees in the MD and HD stands. The thinning of the canopy in the disturbed stands was responsible for a reduced litter depth, greater light intensities and greater soil temperatures on the forest floor. It is known that the opening of the forest canopy and alteration of the forest floor microenvironment affect litter decomposition and reduce the soil nutrients (Qualls et al. 2000). Indeed, we found that the density of shrubs and grasses was significantly increased in the disturbed stands. Such shrubs play important ecological roles in many aspects of forest dynamics, for example, reducing tree growth and fecundity and increasing the opportunity for further shrub establishment by altering the light environment. Our results suggest that grasses will increase in importance with enhanced rates of PWD disturbance.

\subsection{Variations in DOC and DON Concentrations}

The findings of this study are in general agreement with many other studies reporting that DOC and DON concentrations typically peak in the surface soil and subsequently decrease with increasing soil depth, indicating that the surface soil is a major source of dissolved organic matter (Qualls et al. 2000; Michalzik et al. 2001). Temporal variations in soil DOC and DON concentrations are not only significantly affected by biological productivity and soil chemistry but also by climatic seasonality (Embacher et al., 2007; Fujii et al., 2009). For example, early experiments by Christ and David (1996) determined that increased soil temperature and moisture in summer resulted in increased DOC production in the organic horizons of red spruce Spodosols. Soil $\mathrm{pH}$ is considered to be a dominant factor controlling the microbial transformation of organic matter (Adams and Adams, 1983; Kemmitt et al., 2006), and a lower soil $\mathrm{pH}$ under slash pine favored the accumulation of soil $\mathrm{C}$ and thus led to a greater DOC concentration (Shunbao et al., 2012). 
Table 3. Seasonal changes in soil nutrients in the 0-20-cm layer in undisturbed (UD), moderately disturbed (MD) and highly disturbed (HD) forest stands.

\begin{tabular}{|c|c|c|c|c|c|c|c|c|c|}
\hline \multirow{2}{*}{$\begin{array}{l}\text { Stand } \\
\text { Soil depth }(\mathrm{cm})\end{array}$} & & \multicolumn{2}{|l|}{ UD } & \multicolumn{2}{|l|}{ MD } & \multicolumn{2}{|l|}{ HD } & \multicolumn{2}{|c|}{ LSD $(\mathrm{P}<0.05)$} \\
\hline & & $0-10$ & $10-20$ & $0-10$ & $10-20$ & $0-10$ & $10-20$ & $0-10$ & $10-20$ \\
\hline \multirow[t]{5}{*}{ Total N $\left(\mathrm{g} \mathrm{kg}^{-1}\right)$} & AU & $\begin{array}{l}2.31 \\
(0.23)\end{array}$ & $\begin{array}{l}1.56 \\
(0.13)\end{array}$ & $\begin{array}{l}2.97 \\
(0.33)\end{array}$ & $\begin{array}{l}1.75 \\
(0.26)\end{array}$ & $\begin{array}{l}3.04 \\
(0.40)\end{array}$ & $\begin{array}{l}2.24 \\
(0.21)\end{array}$ & 0.65 & 0.41 \\
\hline & WI & $\begin{array}{l}1.73 \\
(0.33)\end{array}$ & $\begin{array}{l}1.06 \\
(0.11)\end{array}$ & $\begin{array}{l}1.43 \\
(0.29)\end{array}$ & $\begin{array}{l}1.37 \\
(0.10)\end{array}$ & $\begin{array}{l}1.93 \\
(0.22)\end{array}$ & $\begin{array}{l}1.22 \\
(0.07)\end{array}$ & 0.57 & 0.19 \\
\hline & SP & $\begin{array}{l}1.22 \\
(0.15)\end{array}$ & $\begin{array}{l}0.88 \\
(0.11)\end{array}$ & $\begin{array}{l}1.46 \\
(0.08)\end{array}$ & $\begin{array}{l}0.91 \\
(0.06)\end{array}$ & $\begin{array}{l}1.73 \\
(0.33)\end{array}$ & $\begin{array}{l}1.06 \\
(0.11)\end{array}$ & 0.43 & 0.19 \\
\hline & SU & $\begin{array}{l}1.04 \\
(0.34)\end{array}$ & $\begin{array}{l}0.78 \\
(0.27)\end{array}$ & $\begin{array}{l}1.26 \\
(0.21)\end{array}$ & $\begin{array}{l}0.92 \\
(0.11)\end{array}$ & $\begin{array}{l}1.66 \\
(0.21)\end{array}$ & $\begin{array}{l}1.11 \\
(0.26)\end{array}$ & 0.52 & 0.45 \\
\hline & LSD & 0.52 & 0.32 & 1.47 & 0.29 & 0.57 & 0.34 & & \\
\hline \multirow[t]{5}{*}{ Total P $\left(\mathrm{mg} \mathrm{kg}^{-1}\right)$} & AU & $\begin{array}{l}266.03 \\
(0.87)\end{array}$ & $\begin{array}{l}205.90 \\
(1.01)\end{array}$ & $\begin{array}{l}241.41 \\
(0.91)\end{array}$ & $\begin{array}{l}189.21 \\
(1.01)\end{array}$ & $\begin{array}{l}221.91 \\
(0.91)\end{array}$ & $\begin{array}{l}180.23 \\
(1.11)\end{array}$ & 1.79 & 2.09 \\
\hline & WI & $\begin{array}{l}109.11 \\
(1.18)\end{array}$ & $\begin{array}{l}90.71 \\
(0.90)\end{array}$ & $\begin{array}{l}98.67 \\
(1.71)\end{array}$ & $\begin{array}{l}91.23 \\
(0.40)\end{array}$ & $\begin{array}{l}80.37 \\
(1.83)\end{array}$ & $\begin{array}{l}78.13 \\
(1.76)\end{array}$ & 3.19 & 2.33 \\
\hline & SP & $\begin{array}{l}183.31 \\
(1.21)\end{array}$ & $\begin{array}{l}173.42 \\
(1.11)\end{array}$ & $\begin{array}{l}171.21 \\
(1.02)\end{array}$ & $\begin{array}{l}154.40 \\
(0.65)\end{array}$ & $\begin{array}{l}173.30 \\
(1.01)\end{array}$ & $\begin{array}{l}160.61 \\
(0.89)\end{array}$ & 2.17 & 1.80 \\
\hline & SU & $\begin{array}{l}171.60 \\
(1.34)\end{array}$ & $\begin{array}{l}109.50 \\
(1.31)\end{array}$ & $\begin{array}{l}104.32 \\
(1.56)\end{array}$ & $\begin{array}{l}111.22 \\
(0.54)\end{array}$ & $\begin{array}{l}95.03 \\
(1.86)\end{array}$ & $\begin{array}{l}89.21 \\
(0.34)\end{array}$ & 3.20 & 1.68 \\
\hline & LSD & 2.19 & 2.06 & 2.53 & 1.30 & 2.77 & 2.15 & & \\
\hline \multirow[t]{5}{*}{ Total K ( $\left.\mathrm{g} \mathrm{kg}^{-1}\right)$} & $\mathrm{AU}$ & $\begin{array}{l}22.07 \\
(0.65)\end{array}$ & $\begin{array}{l}22.81 \\
(0.42)\end{array}$ & $\begin{array}{l}18.07 \\
(0.35)\end{array}$ & $\begin{array}{l}20.16 \\
(0.24)\end{array}$ & $\begin{array}{l}15.29 \\
(0.87)\end{array}$ & $\begin{array}{l}16.41 \\
(0.68)\end{array}$ & 1.32 & 0.92 \\
\hline & WI & $\begin{array}{l}13.31 \\
(1.57)\end{array}$ & $\begin{array}{l}15.77 \\
(0.53)\end{array}$ & $\begin{array}{l}11.65 \\
(0.77)\end{array}$ & $\begin{array}{l}13.27 \\
(0.63)\end{array}$ & $\begin{array}{l}8.21 \\
(1.01)\end{array}$ & $\begin{array}{l}9.10 \\
(0.59)\end{array}$ & 2.33 & 1.17 \\
\hline & SP & $\begin{array}{l}11.98 \\
(1.07)\end{array}$ & $\begin{array}{l}12.13 \\
(0.77)\end{array}$ & $\begin{array}{l}9.98 \\
(1.07)\end{array}$ & $\begin{array}{l}11.13 \\
(0.67)\end{array}$ & $\begin{array}{l}8.14 \\
(0.99)\end{array}$ & $\begin{array}{l}10.98 \\
(0.41)\end{array}$ & 2.09 & 1.27 \\
\hline & SU & $\begin{array}{l}14.57 \\
(0.43)\end{array}$ & $\begin{array}{l}16.19 \\
(0.55)\end{array}$ & $\begin{array}{l}12.23 \\
(0.53)\end{array}$ & $\begin{array}{l}15.19 \\
(0.75)\end{array}$ & $\begin{array}{l}10.35 \\
(0.91)\end{array}$ & $\begin{array}{l}10.66 \\
(0.92)\end{array}$ & 1.31 & 1.51 \\
\hline & LSD & 1.93 & 1.09 & 1.38 & 1.24 & 1.78 & 1.27 & & \\
\hline
\end{tabular}

Note: The standard deviations are listed in parentheses $(n=4)$. AU - autumn, WI - winter, SP - spring, SU - summer.

Anderson et al. (2000) showed that warmer temperatures and higher $\mathrm{pH}$ increased the leaching of DOC from forest mor humus in Sweden. In our study, we observed that the soil $\mathrm{pH}$ was lower under a UD forest stand than under MD and HD forest stands, though the DOC concentrations decreased with soil $\mathrm{pH}$ in all three stands. Overall, the relationship between $\mathrm{pH}$ and $\mathrm{DOC}$ is complex. Strong mineral acids reduce the solubility of the humic acids that decrease DOC concentrations, whereas organic acids tend to increase DOC concentrations (Krug and Frink, 1983). Additionally, $\mathrm{Ca}^{2+}$ and $\mathrm{SO}_{4}{ }^{2-}$ have been shown to affect the DOC concentration via their effects on $\mathrm{pH}$ and ionic strength.
Most disturbances tend to increase the concentration of DOC and DON in the forest soil solution (Kalbitz et al., 2000). In the present study, the DOC values were significantly $(p<0.05)$ higher in every season in the MD and HD forest stands than in the UD stand; this higher DOC concentration in the disturbed forest stands may be attributed to less litter production and a faster decomposition rate compared to the UD stand. However, during spring and summer, the seasonal variation in DON was significantly $(p<0.05)$ lower in the disturbed stands than in the UD stand (Figure 1b). This result may be partially explained by the fact that, after pine wilt disease disturbance, the temperature and moisture conditions are suitable for microorganism 
activity, which may have significantly increased the decomposition rate in the HD stand. Williams and Silcock (2000) reported significant changes in the concentration of extractable DOC over time and observed that extractable DOC was higher during March and August. In the present study, the DOC concentrations were the highest during the summer season in all the stands, which is consistent with previously reported results (Guggenberger and Zech, 1993; Kaiser et al., 2001). The DOC concentrations were the lowest during spring in the UD forest stand and during winter in both the MD and HD stands. Kaiser et al. (2001) suggested that the DOC concentrations of soil solutions are often elevated during summer when microbial activity is high and temperature effects on biological activity are clearly responsible for a large fraction of the DOC. In our experiment, the soil DOC and DON concentrations appeared to be greater during disturbance in autumn and winter, whereas the opposite trend occurred in spring and summer. The seasonal variation in DOC and DON may be largely dependent on the effects of soil temperature on microbial activity and plant productivity and other potential interacting factors (e.g., $\mathrm{pH}$, redox, water table depth), though this requires further assessment. Overall, the results of this study suggest that seasonality could interactively affect soil DOC and DON when forest conversion occurs in disturbed forests.

\subsection{Seasonal Fluctuations of Other Soil Nutrients}

Soil nutrients are important parameters linking plants to the soil. Soil nutrients are very sensitive to small changes in soil conditions (e.g., degradation, erosion) and thereby provide highly accurate and immediate information regarding soil quality because the soil nutrients have a direct influence on tree growth. By integrating data on soil moisture, temperature, $\mathrm{N}$ availability and tree growth, it can be concluded that both soil moisture and $\mathrm{N}$ availability act together to regulate tree growth. In this study, the Pinus massoniana forests in the UD stand grew faster than those in the disturbed stands in response to the greater availability of nutrients and moisture. In agreement with other work (Vitousek et al., 1979), the data from our study indicated that the soil moisture availability was the most limiting factor for the stands, with the soil $\mathrm{N}$ availability also potentially limiting tree growth after PWD disturbance. Our study showed that $\mathrm{NH}_{4}+-\mathrm{N}$ levels were significantly $(p<0.05)$ lower in the HD stand than in either the UD or MD stand during spring and summer, whereas the $\mathrm{NH}_{4}+-\mathrm{N}$ values were significantly higher in the HD stand compared to the other stands during autumn and winter (Figure 1c). This result could be due to immobilization in the soil or plant uptake. Indeed, the retention of $\mathrm{NH}_{4}+-\mathrm{N}$ might be caused by binding to negatively charged surfaces, incorporation into organic matter through chemical reactions or uptake by plants and microbes (Nomnik, 1970; Schimel and Firestone, 1989). In the present study, soil $\mathrm{NO}_{3}^{-}-\mathrm{N}$ concentrations were significantly $(p<0.05)$ higher in each soil layer in the disturbed stands than in the UD stand (Figure 1d). Disturbance in the HD stand resulted in a large number of standing dead trees, increased temperature and enhanced light intensity, which would lead to the rapid decomposition of litter and mineralization of soil organic N. However, a higher soil $\mathrm{NO}_{3}^{-}-\mathrm{N}$ concentration indicates that the potential risk of $\mathrm{N}$ loss is relatively high. This may be partially explained by the possibility that, due to a lack of effective plant utilization and increased surface runoff, $\mathrm{NO}_{3}^{-}-\mathrm{N}$ may be easily lost through surface runoff, denitrification and leakage, thereby reducing the soil $\mathrm{N}$ concentration. At the same time, the soil $\mathrm{NO}_{3}^{-}-\mathrm{N}$ concentration is higher, which can lead to soil acidification and an increase in soil nutrient loss through leaching.

\section{Conclusions}

In summary, PWD disturbance resulted in considerable changes in the microclimate and stand structure of Pinus massoniana forests, which directly led to pronounced changes in DOC, DON and soil nutrients across the disturbance gradient. The soil DOC, $\mathrm{N}$ and $\mathrm{NO}_{3}{ }^{-}-\mathrm{N}$ levels were significantly higher in both the HD 
and MD forest stands compared to the UD forest stand, which may also enhance the risk of $\mathrm{N}$ losses and soil acidification. Furthermore, the Pinus massoniana forests in the UD stand grew faster than those in the disturbed stands in response to the greater availability of nutrients and moisture. Therefore, soil fertility degradation may be exacerbated if steps are not taken to restore the vegetation in disturbed areas.

\section{Acknowledgments}

This study was supported by the National Natural Science Foundation of China (Nos. 31070558 and 30771719). We are grateful to Mrs. FANG Zhen, Anhui Agricultural University, China, for field and laboratory assistance.

\section{References}

Adams, T.M., Adams, S.N. 1983. The effects of liming and soil $\mathrm{pH}$ on carbon and nitrogen contained in the soil biomass. J Agr Sci. 101, $553-558$.

Anderson, S., Nilsson, S.I. 2001. Influence of $\mathrm{pH}$ and temperature on microbial activity, substrate availability of soil-solution bacteria and leaching of dissolved organic carbon in a mor humus. Soil Biol. Biochem. 33, 1181-1191.

Anderson, S., Nilsson, S.I., Saetre, P. 2000. Leaching of dissolved organic carbon (DOC) and dissolved organic nitrogen $(\mathrm{DON})$ in mor humus as affected by temperature and $\mathrm{pH}$. Soil Biol. Biochem. 32, $1-10$.

Anderson, J.M., Ingram, J.S.L. 1993. Tropical Soil Biology and Fertility: A Handbook of Methods. 2nd ed. CAB International, Wallinford, Oxford.

Boissier, J.M., Fontvieille, D. 1995. Biological characteristics of forest soils and seepage waters during simulated rainfalls of high intensity. Soil Biol. Biochem. 27, 139-145.

Brookes, P.D., McKnight, D.M., Bencala, K.E. 1999. The relationship between soil heterotrophic activity, soil dissolved organic carbon (DOC) leachate, and catchment-scale DOC export in headwater catchments. Water Resour. Res. 35, 1895-1902.

Christ, M.J., David, M.B. 1996. Temperature and moisture effects on the production of dissolved organic carbon in a spodosol. Soil Biol. Biochem. 28, 1191-1199.

Embacher, A., Zsolny, A., Gattinger, A., Munch, J.C. 2007. The dynamics of water extractable organic matter (WEOM) in common arable topsoils: I. Quantity, quality and function over a three year period. Geoderma. 139, 11-22.

Filep, T., Kincses, I., Nagy, P.T. 2003. Dissolved organic carbon (DOC) and dissolved organic nitrogen (DON) content of an arenosol as affected by liming in a pot experiment. Arch. Agron. Soil Sci. 49, 111-117.

Fujihara, M. 1995. Succession of secondary pine forests after pine wilt disease in San-yo district. Westeern Jpn. Nat. Hist. Res. 3, 161-171.

Fujii, K., Uemura, M., Hayakawa, C., Funakawa, S., Kosaki, T., Ohta, S. 2009. Fluxes of dissolved organic carbon in two tropical forest ecosystems of East Kalimantan, Indonesia. Geoderma. 152, 127-136.

Guggenberger, G., Zech, W. 1993. Dissolved organic carbon control in acid forest soils of the Fichtelgebirge (Germany) as revealed by distribution patterns and structural composition analysis. Geoderma. 59, 109-29.

Helmke, P.A., Sparks, D.L. 1996. Lithium, sodium, potassium, rubidium, and cesium. In Sparks D.L., 
Page A.L., Helmke P.A., Loepert R.H., Soltanpour P.N., Tabatabai M.A., Johnston C.T., Sumner M. E. (eds.) Methods of Soil Analysis. Soil Science Society of America/American Society of Agronomy, Madison, Wisconsin. pp, 551-574.

Ilstedt, U., Nordgren, A., Malmer, A. 2000. Optimum soil water for soil respiration before and after amendment with glucose in humid tropical acrisols and a boreal mor layer.Soil Biol. Biochem. 32, 1591-1599.

Kaiser, K., Kaupenjohann, M., Zech, W. 2001. Sorption of dissolved organic carbon in soils: effects of soil sample storage, soil-to-solution ratio, and temperature. Geoderma. 99, 317-328.

Kalbitz, K., Solinger, S., Park, J.H., Michalzik, B., Matzner, E. 2000. Controls on the dynamics of dissolved organic matter in soils: a review. Soil Sci. 165, 277-304.

Kemmitt, S.J., Wright, D., Goulding, K.W.T., Jones, D.L. 2006. $\mathrm{pH}$ regulation of carbon and nitrogen dynamics in two agricultural soils. Soil Biol. Biochem. 38, 898-911.

Knight, D.H., Yavitt, J.B., Joyce, G.D. 1991. Water and nitrogen outflow from lodgepole pine forest after 2 levels of tree mortality. For. Ecol. Manage. 46, 215-225.

Krug, E.C., Frink, C.R. 1983. Acid rain and acid soil: a new perspective. Nature. 221, 520-525.

Kuo, S. 1996. Phosphorus. In Sparks D.L., Page A.L., Helmke P.A., Loepert R.H., Soltanpour P.N., Tabatabai M.A., Johnston C.T., Sumner M. E. (eds.) Methods of Soil Analysis. Soil Science Society of America/American Society of Agronomy, Madison, Wisconsin. pp, 869-919.

Lu, S. B., Chen, C. G., Zhou, X. Q., Xu, Z. H., Bacon, G., Yichao Rui, Y. C., Xiaomin Guo, X. M. 2012. Responses of soil dissolved organic matter to long- term plantations of three coniferous tree species. Geoderma. 170, 136-143.

McDowell, W.H., Likens, G.E. 1988. Origin, composition, and fux of dissolved organic carbon in the Hubbard Brook Valley. Ecol. Monogr. 58, 177-195.

McKenzie, N., Coughlan, K., Cresswell, H. 2002. Particle size analysis. In: McKenzie, N., Coughlan, K., Cresswell, H. (Eds.), Soil Physical Measurement and Interpretation for Land Evaluation. CSIRO Publishing, Melbourne, pp. 224-239.

Michalzik, B., Kalbitz, K., Park J.H., Solinger, S., Matzner, E. 2001. Fluxes and concentrations of dissolved organic carbon and nitrogen - a synthesis for temperate forests. Biogeochemistry. 52, 173-205.

Morimoto, K., Iwasaki, A. 1972. The role of Monochamus alternatus (Colleoptera: Cerambycidae) as a vector of Bursaphelenchus lignicolus (Nematoda: Aphelenchoididae). J. Jpn. For. Soc. 54, 177-183 .

Neff, J.C., Chapin, F.S., Vitousek, P.M. 2003. Breaks in the cycle: Dissolved organic nitrogen in terrestrial ecosystems. Front. Ecol. Environ. 1, 205-211.

Nomnik, H. 1970. Non-exchangeable binding of ammonium and amino nitrogen by Norway spruce raw humus. Plant Soil. 33, 581-595.

Prescott, C.E. 1997. Effects of clearcutting and alternative silvicultural systems on rates of decomposition and nitrogen mineralization in a coastal montane coniferous forest. For. Ecol. Manage. 95, 253-260. 
Qualls, R.G. 2000. Comparison of the behavior of soluble organic and inorganic nutrients in forest soils. For. Ecol. Manage. 138, 29-50.

Schimel, J. P., Firestone, M.K. 1989. Inorganic N incorporation by coniferous forest floor material. Soil Biol. Biochem. 21, 41- 46.

Schimel, J.P., Bennett, J. 2004. Nitrogen mineralization: challenges of a changing paradigm. Ecology. 85, 591-602.

Suarez, D.L. 1996. Beryllium, magnesium, calcium, strontium, and barium. In Sparks D.L., Page A.L., Helmke P.A., Loepert R.H., Soltanpour P.N., Tabatabai M.A., Johnston C.T., Sumner M. E. (eds.) Methods of Soil Analysis. Soil Science Society of America/American Society of Agronomy, Madison, Wisconsin. pp, 575-601.
Vitousek, P.M., Gosz, J.R., Grier, C.C., Melillo, J.M., Reiners, W.A., Todd. R.L. 1979. Nitrate losses from disturbed ecosystems. Science. 204, $469-$ 474.

White, P.S., Pickett, S.T.A. 1985. Natural disturbance and path dynamics: an introduction. In: Pickett, S.T.A., White, P.S.(Eds.), The Ecology of Natural Disturbance and Patch Dynamics. Academic Press, Orlano, EL. pp, 3-13.

Williams, B.L., Silcock, D. 2000. Impact of $\mathrm{NH}_{4} \mathrm{NO}_{3}$ on microbial biomass $\mathrm{C}$ and $\mathrm{N}$ and extractable DOM in raised bog peat beneath Sphagnum capillifolium and S. recurvum. Biogeochemistry. 49, 259-276. 